\title{
A „Longest Kill 2017” igazságügyi fegyverszakértői értékelése
}

2 017-ben a kanadai Globe and Mail hírforrás [1] számolt be egy szinte hihetetlen lőtávolságú halálos találatról, amelyet a kanadai különleges műveleti erők mesterlövésze ért el Irakban, egy 3540 méter távolságban lévő, merényletre készülő ISIS terrorista leküzdésével. A mesterlövész a cikk szerint McMillan TAC-50 puskával, és feltehetően a puskával járatos Hornady.50 BMG Match $^{\mathrm{TM}}$ töltény $A-M A X ®$ lövedékével érte el ezt az eredményt.

Az eset hamar bejárta a világhálót. Azt hiszem minden, a mesterlövész szakmában kicsit is járatos szakember fantáziáját megmozgatta a történet valóságtartalma.

\section{1. ábra. A nevezetes lövésröl készült vázlat a kanadai Globe and Mail lap nyomán [1]}

\section{A világ leghosszabb mesterlövész lövése}

Irakban, a kanadai speciális erők tagja megdöntötte a hadtörténelem igazolt legnagyobb távolságból leadott halálos lövésének világrekordját az elképesztő 3540 m-es távon

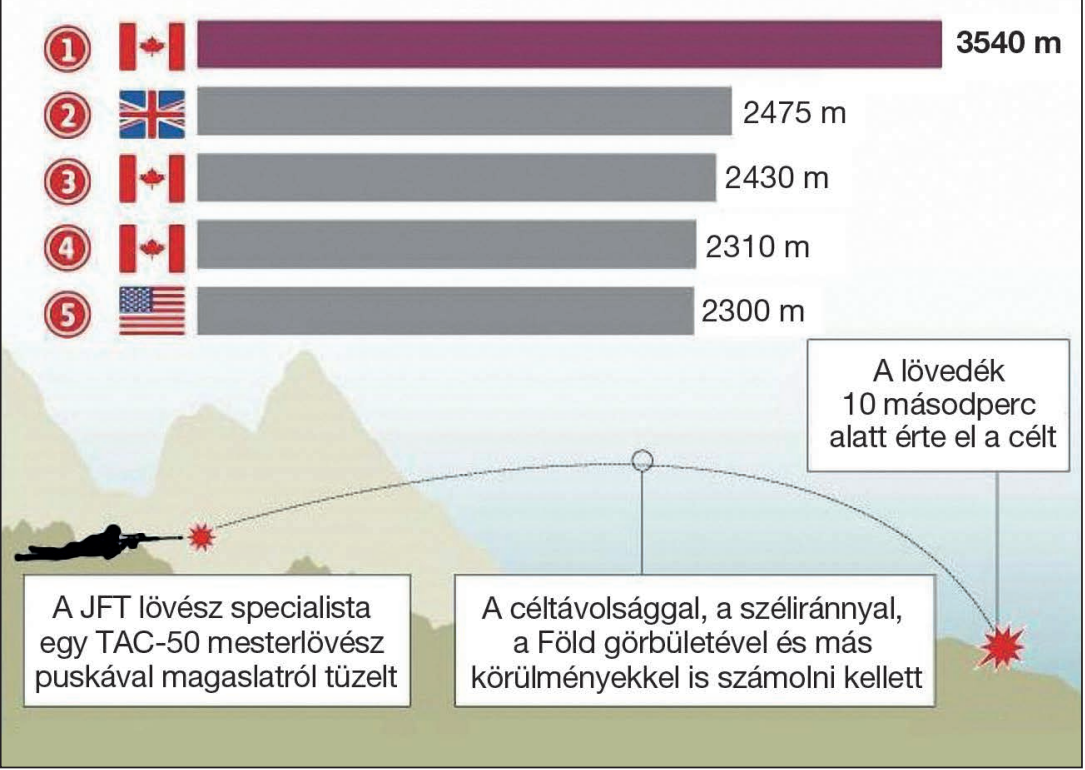

Igazságügyi fegyverszakértőként és a nagy űrméretű, mesterlövész Gepárd M1-es puska tervezőjeként (valamint a Gepárd fegyvercsalád fejlesztő-vizsgáló csapat vezetőjeként), most kizárólag tudományos alapon kívánok a kérdéssel foglalkozni. Vizsgálni kívánom a lövedék hatásosság képességét (a becsapódási energiáját) a célban, a pontosság képességét, és mindezekre a környezeti viszonyok befolyását. Mindezekhez a vizsgálatokhoz a tárgyban írt tanulmányaimban foglaltakat ([2] - [5]) kívánom elsősorban felhasználni, természetesen a lőtéren és harcászati gyakorlatokon végrehajtott lövészeteim során a nagy ürméretű mesterlövész és a romboló puskákkal szerzett gyakorlati tapasztalataimmal (legalább tízezer lövés) együtt.

Előre kell bocsátanom, hogy nem az eredeti történet harcászati-műszaki szempontból való cáfolata volt a célom, hanem lehetőségeim és tudásom mértékében leásni a történet fizikai valóságához.

Dr. Piroska György úr szerzőtársammal - aki több évtizeden keresztül a Haditechnikai Intézet ballisztikai szakembereként dolgozott és szakmai ismeretei vitathatatlanok - a következő kérdésköröket szándékoztuk körbejárni:

- volt-e a lövedéknek elégséges mozgási energiája 3540 m-en, hogy mozgás-, vagy harcképtelenné tegye a célszemélyt?

- Meg voltak-e a műszaki feltételei a találat elérésének adott fegyver-lövedék rendszer esetén?

Válaszainkat a következőkben fogalmazzuk meg:

\section{A haLÁlos találat LöVEdÉKÉNEK BECSAPÓDÁSI ENERGIÁJA}

Alapvetés: A biztos harcképtelenné tevő becsapódási energia nem lehet kevesebb 250 J értéknél. Egy a sebesülési
ÖSSZEFOGLALÁS: A közelmúlt elhíresült és a katonai történelemben a világcsúcsnak számító, legtávolabbi megerősített halálos lövésnek minősített kanadai mesterlövész által kiváltott lövést kíséreli meg a cikk két igazságügyi fegyverszakértő szemszögéből értékelni.

KULCSSZAVAK: távlövés rekord, kanadai mesterlövész, mesterlövész puska, mesterlövész töltény
ABSTRACT: Recently became the world record for the longest confirmed kill shot in military history, make by Canadian sniper. Two hungarian Justice weapons experts attempt to analyse this story from ballistician perspective.

KEY WORDS: Record kill shot, Canadian sniper, sniper rifle, match ammunition

\footnotetext{
* Dr. Földi Ferenc PhD, nyá. ezredes, NKE Katonai-Műszaki Doktori Iskola, igazságügyi fegyverszakértő. ORCID: 0000-0002-0513-8493

** Dr. Piroska György PhD, igazságügyi fegyverszakértő végezte a külballisztikai számításokat és látta el az írást a szükséges ballisztikai adatokkal. ORCID: 0000-0001-6097-5801
} 
traumákat elemző mű [6] részletesen ismerteti, hogy a második világháború tapasztalatai alapján a fő hadviselő nemzetek milyen mértékűre értékelték saját katonáik ellenálló képességét. A skála igen tág határok között mozog, például a franciák $40 \mathrm{~J}$, a szovjetek $240 \mathrm{~J}$ értékűre adták meg a katonáik harcképességét megszüntető becsapódási energiát. Ezek figyelembevételével elemzésünk során minimálisan $250 \mathrm{~J}$ kinetikus energiával rendelkező lövedéket tekintünk elégségesnek. Az Afganisztánban a nyolcvanas években folyó háború, és a jelenlegi harcok tapasztalatait elemezve talán joggal feltételezhető, hogy a közel-keleti harcosok tűrőképessége sem lehet rosszabb, mint a szovjeteké volt. Ezért felső mértéknek - némi rátartással - a közölt energiamennyiséget adtam meg.

Ebből kiindulva, most már a konkrét külballisztikai adatok tükrében, a Hornady A-MAX ${ }^{\circledR} 750 \mathrm{gr}$, azaz 48,6 g tömegű lövedéke [7] a $250 \mathrm{~J}$ becsapódási energiát mintegy $102 \mathrm{~m} / \mathrm{s}$ becsapódási sebesség mellett szolgáltatja. A pályamenti sebességi adatok szerint a lövedék, a maximális $(\sim 7200 \mathrm{~m})$ lőtávolságban ezt a sebességet meghaladja $(184 \mathrm{~m} / \mathrm{s})^{1}$. A lövedék pályamenti kinetikus energiája maximális lőtávolságban is több mint háromszorosa (823 J) a szükséges becsapódási energiának. Ebből következik, hogy a lövedéket nem lehet olyan nagy vízszintes távolságra ellőni, amelyen belül ne őrizné meg ölőképességét. A vizsgált céltávolságban a mozgási energia legalább $1388 \mathrm{~J}$, amely elégséges a célszemély harcképtelenné tételéhez.

Összefoglalva kijelenthető, hogy a hivatkozott lövedék 3540 méter lőtávolságban egyértelműen képes halálos sebzés kiváltására.

\section{A találat VaLóSZínÜSÉGE}

Milyen pontosságú fegyver-töltény részrendszer² szükségeltetett a biztos találat eléréséhez?

A [2] tanulmányomban megkíséreltem a mesterlövész pontosság képesség követelményeit számszerűsíteni; megfogalmaztam, hogy a biztos találat nemzetközileg elfogadott kritériuma, hogy a pontosság képesség MOA-ban ${ }^{3}$ kifejezve megfeleljen az adott lőtávolságon a cél eredményesen támadható felületének. Képletben kifejezve ezt a követelményt ${ }^{4}$ :

$M O A=2 \cdot 60 \cdot \operatorname{arctg}\left(\frac{\frac{500-d_{k}}{2}}{L \cdot 10^{5}}\right)=120 \cdot \operatorname{arctg}\left(\frac{s_{\text {cél }}}{35 \cdot 10^{5}}\right)$,

ahol:

500 az emberi test szélessége mm-ben kifejezve

$d_{k}$ a lövedék ürméreti átmérője mm-ben = 12,7 [1; A találatok megítélése szakaszban]

$L$ a céltávolság hektométerben $=35,4$

$s_{\text {cél }}=\frac{(500-12,7)}{2} \sim \frac{488}{2}=244$ mm (a szóráskép talpkörének a sugara).

Ezekkel az adatokkal:

$$
M O A=120 \cdot \operatorname{arctg}\left(\frac{244}{35,4 \cdot 10^{5}}\right)=0,474
$$

Ugyanígy, az oldalnézetű emberi test legalább $250 \mathrm{~mm}$ méretére vonatkoztatva $s_{\text {cél }}=118 \mathrm{~mm}$, ebből a MOA nem lehet rosszabb, mint 0,24 .

Nem lehet semmiféle müszaki, és/vagy külballisztikai érvvel tagadni a találat lehetőségét ilyen lőtávolságon sem, ugyanakkor a célzott lövés biztos találata (mesterlövészeknél hatásos találat az első lövésre) legalább is kétséges, mert:
- kiemelkedően precíz fegyver szükséges (bár nem kizárt: mert az [1] szerint ez a McMillan TAC-50-es puska volt, amelyik valóban kiemelkedik a mezőnyből);

- kiemelkedően precíz töltény szükséges (ez sem zárható ki, például a McMillan cég is elsősorban a Hornady A-MAX ${ }^{\circledR}$-ot ajánlja ehhez a puskához);

- a három és fél kilométeres röppályán azonosan homogén légnemű közeg szükséges, hogy a lövedék a célzáskor beállított röppályát járja be a célig;

- a pontos (biztos) találat négy alapfeltétele a fegyver, a lövedék, a lövész megfelelősége és a légnemú közeg stabil állapota. Az adott esetben a pontosság azt jelenti, hogy a felsorolt elemekből összeállt rendszereredő pontossága nem lehet rosszabb $(0,5$ méter átlagos célszélességet alapul véve), mint 0,48 MOA, a (2) képlet eredménye alapján. Meg kell jegyezni azonban, hogy az összefüggés nem lineáris, a lőtávolság függvényében a röppályák némiképp széttartanak. Ez az elemzés is csak akkor igaz, ha a célszemély éppen merőlegesen a lőirányra áll, de ha a lövőnek oldalt fordulva, akkor a 0,24 MOA alapján, a 100 méteres a szórásképnek már csak $7 \mathrm{~mm}$ átmérőjű kört, ami már nem esik messze az egy találat ütötte lyuk 6,35 mm-es félátmérőjétől;

- az sem elhanyagolható szempont hogy - az [5] forrás alapján -, a lövedék mintegy 10 másodperc alatt járta be a röppályát. Ennyi idő alatt a célszemély biztosan nem marad teljesen mozdulatlan. Kiszámítható, hogy a test szinte természetesnek tekinthető, legalább \pm 1 fokos kilengése mellmagasságban már 206 mm-rel csökkenti a célfelület $s_{\text {cél }}$ méretét a függőleges szimmetriatengelyhez képest, ezzel javított MOA képességet követel meg a humán és műszaki eszközrendszertől;

- a legfontosabb adat a pontosság képesség megítéléséhez, hogy a MOA értékkel jellemzett szóráskúp talpkör középpontja milyen mértékben tér el a célfelület függőleges szimmetria vonalától. Ezeket az eltéréseket is le kell vonni az $s_{\text {cél }}$ nagyságából. Nos, ez a tény is csökkenti a biztos találathoz mindenképp szükséges MOA értéket, akár a felére is;

- ezen a távolságon a lövedék oldalgása több méter lehet (az orosz 12,7 B32 lövedéké már 2000 m-en is 1,19 m a lőtábla szerint [9; 6. Táblázat 209. o.]), amit az adott céltávolságra és meteorológiai viszonyokra érvényesen csak lőkísérletek során elvégzett mérésekkel lehet meghatározni;

- mindezek felett a megfelelő szóráskép mellett a biztos találat alapvető követelménye a lőtávolság nagyon pontos ismerete. Ennek a hiányában hiába érkezne oldalban a cél tengelyébe a lövedék, nagyon könnyen előfordulhat, hogy az elrepül a cél felett, vagy előtte csapódik a talajba;

- kiváló látási viszonyok szükségesek végig a lővonalon. Irakban, a nem helyi lakosoknak a hőséget csak amiatt lehet elviselni, mert folyamatos a légmozgás (egyszerübben folyton fúj a szél), emiatt viszont a szálló por és a talajmenti légremegés mindent elfed, homályosan tesz csak láthatóvá - főleg ekkora távolságban. Hazai gyakorlatban a táborfalvai nyári időjárási és talajviszonyok mellett már 1200 méter távolságban is legalább egy célszélességet ugrált a célkép az irányzójel függőleges fonala körül, a meleg levegő feláramlása miatt;

- a fegyver optikai irányzéka külön bekezdést igényel. Az irányzék nagyítása és felbontása extrém kell, hogy legyen. Nem találtam adatot, hogy például egy Leupold VX-6 7-42×56 céltávcső, amelyik talán még valóban használható ezen lőtávolságra, milyen vonalpár/mm 


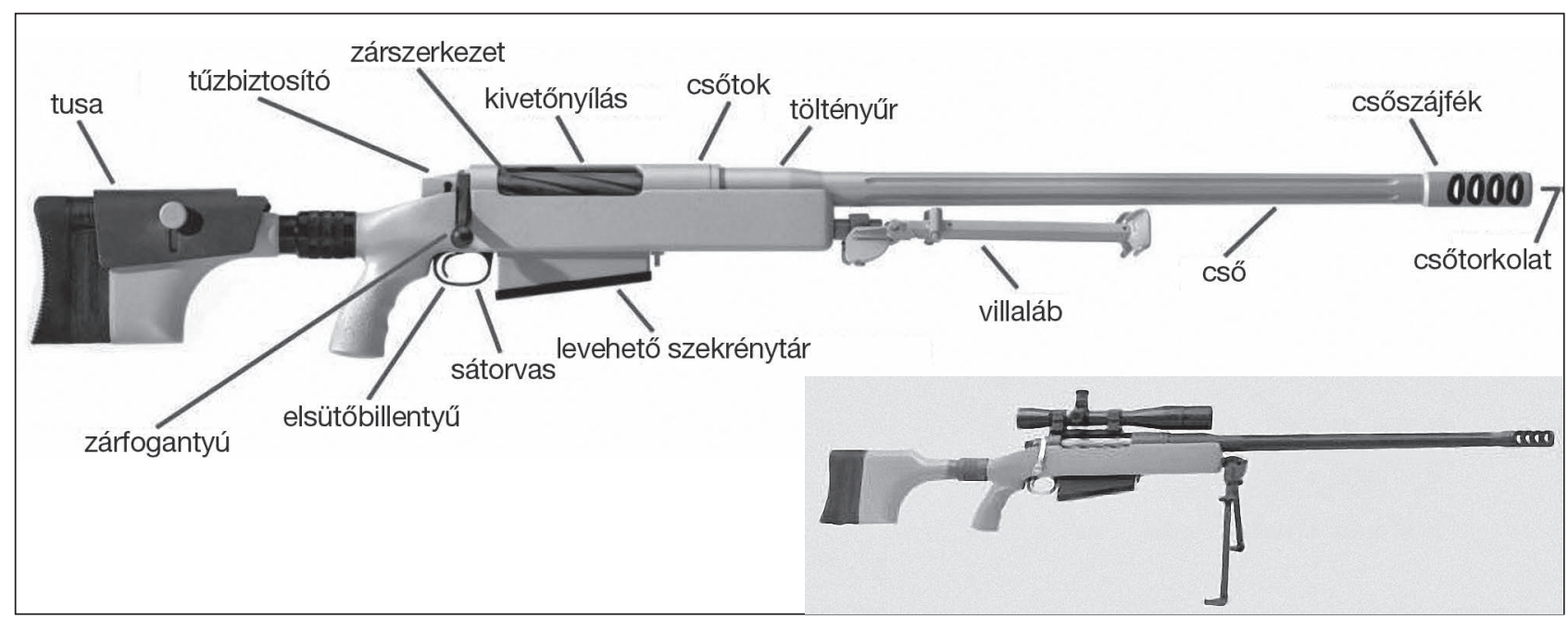

2. ábra. 12,7 x 99 mm-es NATO McMillan TAC50 mesterlövész puska [8]

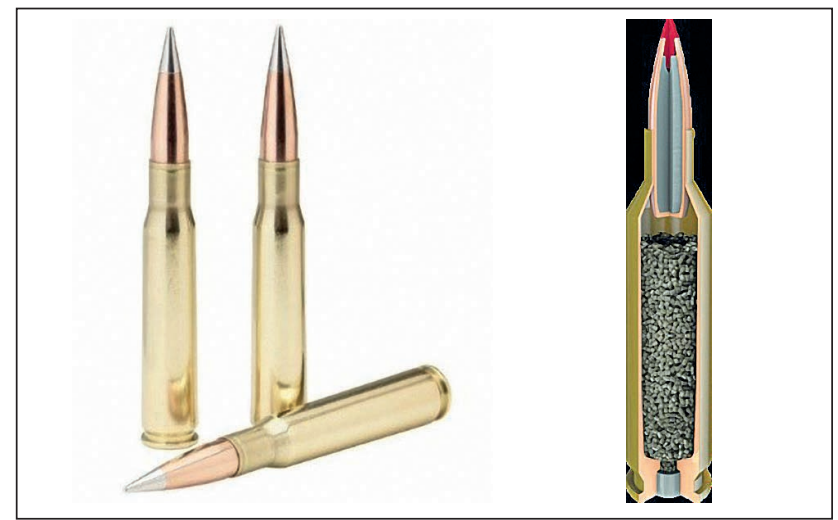

3. ábra. Hornady 50 BMG Match ${ }^{\mathrm{TM}}$ töltény 750 gr A-Max® lövedékkel és metszete [7]

felbontással rendelkezik, azaz a 3500 méter távolságból mi ismerhető fel, és mi azonosítható a látómezőben. Birtokolok azonban egy Bresser ZOOM 20-60×60 Spektívet. Ezzel a műszerrel és a Google Earth ${ }^{T M}$ programmal végzett 3500 méteres tereptárgy felvételekkel, a csókakői vár mellvédjéről - háromlábas fix állványról - végeztem néhány mérést a felismerhetőség megállapítására. Délelőtt, hátfényben, napsütötte páramentes időben, fehérre meszelt házfal háttérrel. A következőket tapasztaltam:

o 42-szeres nagyítással egy sötét emberalak felismerhető, de nem azonosítható,

o 60-szoros nagyítással ugyanezen emberalak felismerhető, de továbbra sem azonosítható,

ugyanakkor, a mesterlövész feladatvégzésben a célpont azonosítása elengedhetetlen. Ebben az esetben a lövész honnan tudta ki a célpont, és milyen háttér előtt lőtt? A vázlat alapján a talaj jöhetett szóba, amely nem a legjobb kontrasztot biztosítja. Feltehető, hogy a lövészt egy közeli helyzetű kisegítő ember látta el információkkal;
- az optikai irányzótávcső beszabályozásának alapfeltétele, hogy az oldal és a magassági beálító kerék egy kattanásra hány tized vonásra mozdítja el a célkereszt középpontját, azaz milyen finomsággal lehet beállítani a lőszöget, amely a lőtávolságot határozza meg. Ezen a lőtávolságon az igen precíznek számító egytized vonás $(00-00,1 \sim 0,36$ MOA) beállítási határérték már közel 0,35 m eltérést visz a becsapódási pont helyzetébe (lásd: 3.2 pontban).

\section{A KÜLbalLISZTIKAI SZAKÉrTő ÉSZREVÉteleI}

A megadott és a hozzáférhető adatok birtokában az első lépésként meghatároztam a lövedék röppályájának leglényegesebb numerikus adatait, amelyek alkalmasak voltak a fontosabb következtetések levonására. Ezeket az adatokat egyrészt a röppálya-görbék megrajzolásában, másrészt a jellemző pontok táblázatos közlésével tettem áttekinthetővé.

\subsection{AZ A-MAX® LÖVEDÉK RÖPPÁLYÁl}

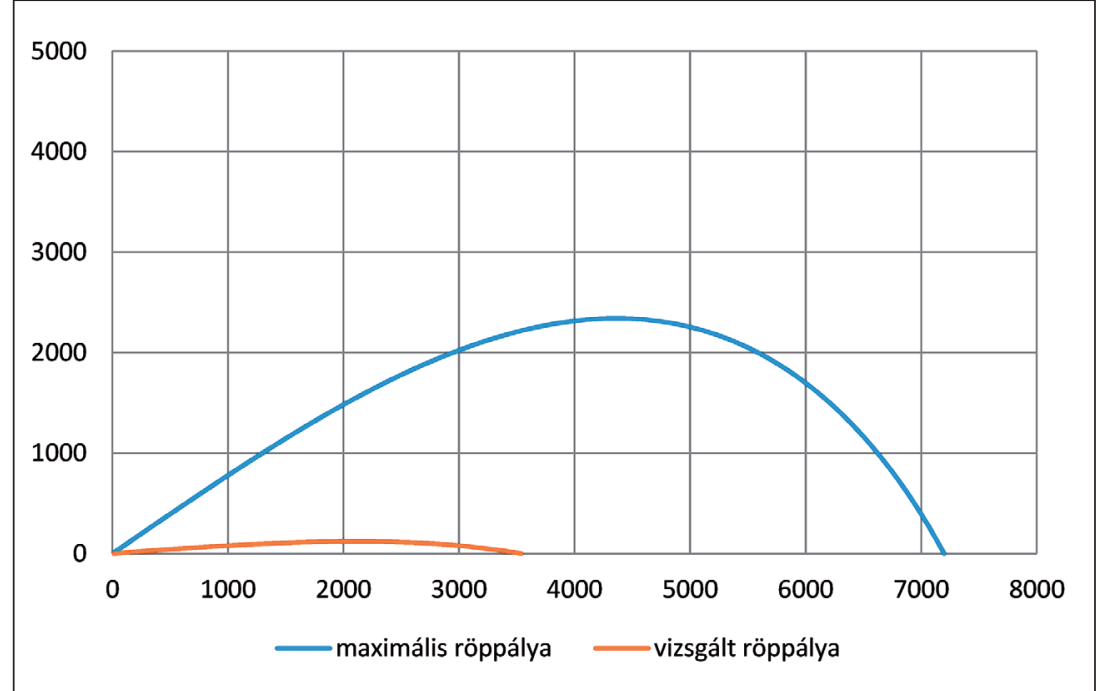

4. ábra. A lövedék röppályáinak képe (a kék a maximális, a barna a 3540 m-es lötávolság) 
1. táblázat. A röppályák főbb jellemző numerikus adatai

\begin{tabular}{|r|r|r|c|r|r|c|}
\hline \multicolumn{7}{|c|}{ Vizsgált röppálya } \\
\hline $\boldsymbol{x}(\mathbf{m})$ & $\boldsymbol{y}(\mathbf{m})$ & $\boldsymbol{z}(\mathbf{m})$ & $\boldsymbol{v}(\mathbf{m} / \mathbf{s})$ & $\phi(f o k)$ & $\boldsymbol{t}(\mathbf{s})$ & Megjegyzés \\
\hline 0,00 & 0,00 & 0,00 & 823 & 5,10 & 0,00 & Torkolat \\
\hline 2108,00 & 122,83 & 0,00 & 321 & 0,00 & 4,22 & Tetőpont \\
\hline 3537,02 & 0,23 & 0,00 & 239 & $-10,80$ & 9,47 & Végpont \\
\hline \multicolumn{7}{|c|}{ Maximális röppálya } \\
\hline 4,00 & 0,00 & 0,00 & 823 & 38,52 & 0,00 & Torkolat \\
\hline 4363,20 & 2341,32 & 0,00 & 158 & $-0,01$ & 17,76 & Tetőpont \\
\hline 5219,84 & 2181,65 & 0,00 & 147 & $-21,38$ & 23,60 & Min. sebesség \\
\hline 7198,26 & 1,00 & 0,00 & 184 & $-64,83$ & 42,08 & Végpont \\
\hline
\end{tabular}

$y(m)$ Röppálya magassági koordináta; $x(m)$ Röppálya lőirányú koordináta;

$z(\mathrm{~m})$ Röppálya oldalgási koordináta; $v(\mathrm{~m} / \mathrm{s})$ Röppályamenti sebesség;

$\phi$ (fok) Röppálya állásszög; $t$ (s) Röpidő

\subsection{AZ INDULÓSZÖG VÁLTOZÁSÁNAK HATÁSA A BECSAPÓDÁSI PONT HELYZETÉRE}

Adott fegyver - lőszer - lövész rendszer esetén, adott meteorológiai és földrajzi feltételek között a lövedék által befutott röppálya a csőfurat tengelyének a vízszintessel bezárt szögétől, a lőszögtől függ. Ebből következik, hogy a röppálya bármely pontjának $x-y$ koordinátája is a lőszög függvénye. Feltételezve, hogy megfelelően kicsiny $\delta$ lőszögváltozás esetén a röppálya alakváltozása elhanyagolható, az a csőtorkolati pont körül $\pm \delta$ értékkel forgatható. A 3500 méteres röppályát 00-00,1 (egytized vonással) elforgatva, a becsapódási pont helyzetében közel 0,35 méter magassági változást eredményez.

A fenti feltételek mellett megvizsgálva, hogy a pontlövés mellett milyen pásztázás adódik, azt kapjuk, hogy a közel 3500 méteres céltávolság térségében, 1,7 méter magas cél esetén a pásztázási távolságtartomány mindössze 9 méter, azaz legfeljebb ekkora távolságmérési hibát lehetne megengedni.

A fegyver műszaki megvalósításából adódik, hogy ha a villaállvány talppontjához képest a válltámasz magassági helyzete 0,1 mm-rel megváltozik, akkor ez önmagában 0000,13 lőszőgváltozást, azaz a közel 3500 méteres távolságban 0,45 méter becsapódási pont magasságváltozást eredményez.

\subsection{A METEOROLÓGIAI FELTÉTELEK VÁLTOZÁSÁNAK HATÁSA A BECSAPÓDÁSI PONT HELYZETÉRE}

A meteorológiai hatások közül a lőírányú, és az oldalszélnek, a légköri hőmérsékletnek valamint a légnyomásnak van jelentős hatása a röppályára.

Ha például 0,5 m/s-os, a lőiránnyal $45^{\circ}$-os szöget bezáró, az egész röppályán állandó nagyságú szellőt feltételezünk, akkor a becsapódási pont magassága közel 0,3 méterrel az oldalgás 1,8 méterrel változik meg a közel 3500 méteres lőtávolságon.

\subsection{A LŐELEMSZÁMÍTÁS PONTOSSÁGI KORLÁTAI}

A közel 3500 méteres lőtávolság esetén a cél eltalálása vagy szerencse dolga, vagy a sikeres lövés megkísérlése elképzelhetetlen ballisztikai számítógép igénybevétele nél- kül. A lőelemek kiszámításához viszont igen pontosan kell megadni:

- a fegyver-lőszer rendszer múszaki adatait, elsősorban az induló szöghibát, a lövedék kezdősebességét, tömegét, átmérőjét, alaktényezőjét (a használt légellenállás függvényre vonatkozóan), esetleg hosszát, és a fegyvercső huzagemelkedését;

- a tüzelőállás és a célpont egymáshoz viszonyított elhelyezkedését, tengerszint feletti magasságát, esetleg földrajzi szélességét;

- a légkör pillanatnyi állapotára vonatkozó adatokat, úgymint szélsebesség, lőirányra vonatkoztatott szélirány, légnyomás, léghőmérséklet.

Ebből az adathalmazból határozza meg a ballisztikai számítógép a lőszöget és az oldalszöget, amelyet vagy a lövész manuálisan állít be a céltávcsövön, vagy az automatikusan állítódik be az irányzó eszközön.

A bemenő adatok közül a fegyver-lőszer jellemzők kielégítő pontossággal megadhatók. A geodéziai adatok már nehezebben, mivel - áló alak méretű célt feltételezve - az egymáshoz viszonyított helyzetet mind távolság, mind magasság (vagy célhelyszög) tekintetében legalább $\pm 0,5 \mathrm{~m}$ pontossággal kellene megadni, ami napjaink lézer távmérőivel és GPS vevőivel is kérdéses. Legnagyobb probléma a meteorológiai adatokkal van, hiszen a pillanatnyi adatokat a várható röppálya mentén végig kellene ismerni, ami gyakorlatilag nem biztosítható, legfeljebb feltételezhető. A közepes, esetleg becsült adatokkal a számítás eredménye mindenképpen csak közelítő érték lesz.

\section{5. ÖSSZEGZÖ ÉSZREVÉTEL}

A TAC-50-es fegyverből .50 BMG Match ${ }^{T M}$ töltény A-MAX® lövedékével leadott sikeres lövés minden elismerést megérdemel, de az eredmény inkább a szerencsének köszönhető, mint a fegyver-lőszer-lövész rendszer és az azt támogató felderítő-lőelemszámító segédrendszer sikeres működésének.

\section{ÖsszEGzés}

Az a megalapozott véleményünk, hogy bár műszaki tudományok eszközkészletével nem lehet az esemény bekövetkeztét kizárni, de elfogadható valószínűség melletti reprodukálhatósága bizonyosan kizárható.

Nem tartjuk reálisnak azt a lehetőséget sem, hogy a fegyvert egy olyan kívülről vezérelt, merev állványba fogták fel, amely:

- fokozatmentesen lett volna képes álítani a csőfurat tengelyének magassági és oldalszögeit;

- lehetővé tette volna, hogy a fegyvercső legalább 4 ms ideig kizárólag a csőfurat tengelyében tudjon csak hátrasiklani (a csőtengely térbeli kimozdulás megakadályozása miatt);

- kellően merev kialakítása nem engedte volna meg a fegyverre ható káros rezgések kialakulását a lövésfolyamat alatt;

- tökéletesen össze lett volna hangolva az optikai irányzóműszerrel és egyéb célzást segítő műszerekkel; 
A történet nem kétségbe vonható, azonban egy ilyen lövés reprodukálásának matematikailag igen csekély a valószínúsége.

A hír megjelenése óta sorra jelennek meg a világhálón hírek az ezt a lőtávolságot is meghaladó pontlövésekről [10], amint az amúgy várható is volt.

\section{FoRRÁsOK}

[1] Canadian elite special forces sniper makes record-breaking kill shot in Iraq https://www.theglobeandmail.com/ news/politics/canadian-elite-special-forces-sniper-sets-record-breaking-kill-shot-in-iraq/article35415651/ [2018.02. 12.];

[2] Földi Ferenc: Gondolatok a pontosságról. Hadmérnök, 2006. 1. évf., 1. szám http://www.hadmernok.hu/archivum/2006/1/2006_1_foldi2.html;

[3] Földi Ferenc: Gondolatok a hatásosságról. Hadmérnök, 2006. 1. évf., 3. szám http://www.hadmernok.hu/archivum/2006/3/2006_3_foldi2.html;

[4] Földi Ferenc: Gondolatok a használhatóságról. Hadmérnök, 2006. 1. évf., 3. szám http://www.hadmernok.hu/archivum/2006/3/2006_3_foldi1.html;

[5] Földi Ferenc: Gondolatok a fegyverek szerepéről a harcban. Hadmérnök, 2006. 1. évf., 1. szám. http://www.hadmernok.hu/archivum/2006/1/2006 1 foldi1.html;

[6] Karl G. Seiller-Beat P Kneubuehl: Wound Ballistics. Elsevier Science B.V., Asterdam, 1994.

[7] 50 BMG 750 gr A-max® MatchTM; https://www.hornady.com/ammunition/rifle/50-bmg-750-gr-a-max-match\#!/ [2018.06.20.];

[8] McMillan Owners Manual Final; http://www.mcmillanfirearms.com/wp-content/uploads/psc-pdf-manager/36_MAC1307-TAC-50-OWNERS-MANUAL-FINAL.PDF [2018.06.20];

[9] Риководство по 12,7-мм пулемету „Утес” (НСВ - 12.7). Оргена Трудового Знамени Военное Издательство Министерства Обороны СССР; Москва - 1978; „Секретно” mi-nősítéssel.;

[10] New long range shooting record - 3720 yards. YouTube. Közzététel: 2015. máj. 8. https://www.youtube.com/watch?v=t5m_vBSAFoA 2018.06.20].

\section{JEGYZETEK}

1 A McMillan TAC-50-es puska veszélyzónája 5,5 mérföldes, $(\sim 8,8 \mathrm{~km})$, de ez - a lövedék felpattanás miatt - mindig nagyobb a maximális lőtávolságnál [8; Part 2 10. 7 p.].

2 A fogalom magyarázatát lásd: [2]-ben részletesen kifejtve.

3 MOA, Minute of Angle, a.m. szögperc, annak az egyenes kúpnak a nyilásszöge, amely talpkörének sugara nem nagyobb, mint a célfelület legkisebb méretének a fele, ha a talpkör és a célfelület geometriai középpontja egybeesik. Nem azonos jellemző a magassági és oldalirányzási szög szögpercben kifejezett értékével.

4 [2]: a [3] jelű képlet.

\section{HM ZRÎNYI TÉRKÉPÉSZETI ÉS KOMMUNIKÁCIÓS SZOLGÁLTATÓ KÖZHASZNÚ NKFT.}

Telephely: 1024 Budapest II., Szilágyi Erzsébet fasor 7-9.・ $\ 1276$ Budapest 22, Pf. 85・꿀 +36 (1) 336-2030・www.topomap.hu・hm.terkepeszet@topomap.hu

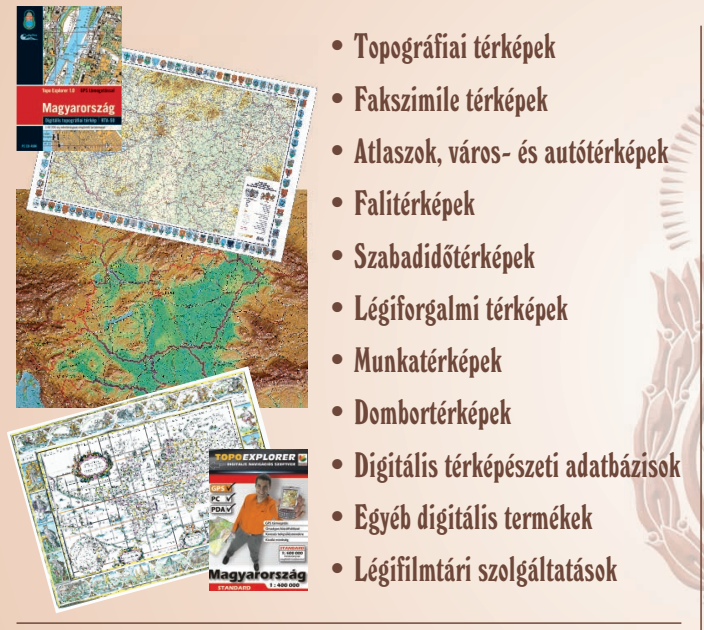

ÜGYFÉLSZOLGÁLAT ÉS TÉRKÉPBOLT:

1024 Budapest II., Fillér u. 14

푤 +36 (1) 212-4540・uǵvfelszolgalat@topomap.hu Nyitva tartás: hétfö-péntek 9.00-15.00
- PrePress - Nyomdai elókészítés

- szöveǵ, grafika- és képfeldolgozás, kiadványszerkesztés

- ellenőrző nyomatok, digitális proofok elóállítása

- bel-és kïltéri tablók, bannerek nyomtatása

- hagyományos és elektronikus montírozás, színrebontás

- nyomóformák előállítása nyomdai filmról, illetve CTP-technológiával

- Gyorssokszorosítás

- színes és fekete-fehér másolás/nyomtatás 330 x 487 mm méretig

- Press - Nyomtatás

- ofszetnyomtatás négy-, illetve hatszínnyomó gépeken, 89 x 126 cm méretig

- PostPress - Kötészeti feldolgozás

- felületnemesítés fóliázással, laminálással 167 cm szélességig

- hajtogatás, spirálozás, sorszámozás

- összehordás, irkakészités, ragasztókötés

- kasírozás, táblakészítés, aranyozás

- szortiment könyvkötészet

- Vákuumformázás

- vákuumformázó szerszámok, terepasztalok előállitása CNC-technológiával - vákuumformázás

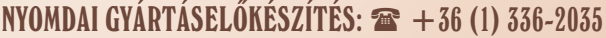

